\title{
International Journal for Crime, Justice and Social Democracy
}

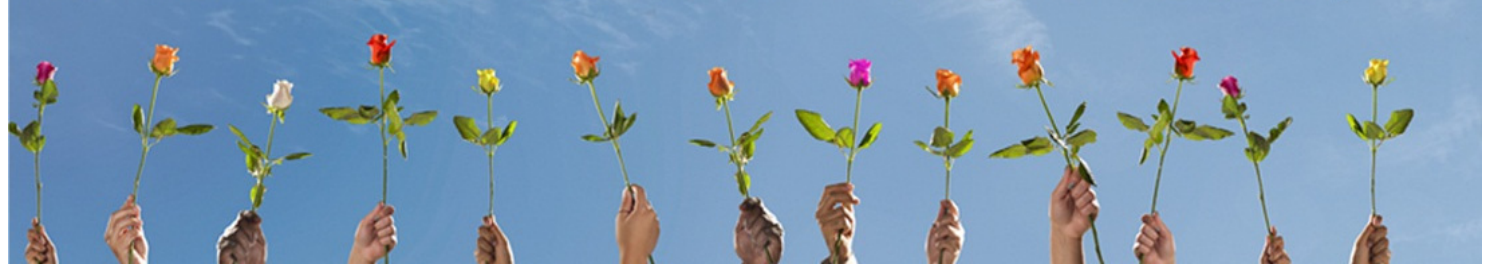

\section{Punishment, Democracy and Transitional Justice in Argentina (1983-2015) ${ }^{1}$}

\section{Diego Zysman Quirós}

Universidad de Buenos Aires, Argentina

\begin{abstract}
Latin America has neither suffered the majority of mass atrocities in the contemporary world nor the worst of them but, after a sustained period of transition to democracy, it holds the record for the most domestic trials for human rights abuses. Argentina is an emblematic case in Latin America and the world. Due to the early development of its human rights trials, their social impact and their scale, it has a leading role in what is known as 'the justice cascade'. Until recently, leading scholars in sociology of punishment have studied the penality of 'ordinary crimes' through causally deep and global narratives largely from the perspective of the Global North. State crimes and regional paths of transitional justice have been neglected in their accounts. This paper will question this state of affairs - or 'parallelism' - through an exploration of the punishment of both 'common crimes' and 'state crimes' in Argentina, thus contributing to the growing body of scholarship on southern criminology.
\end{abstract}

\section{Keywords}

Punishment; democracy; transitional; justice; state; crime.

\section{Please cite this article as:}

Zysman Quirós D (2017) Punishment, democracy and transitional justice in Argentina (19832015). International Journal for Crime, Justice and Social Democracy 6(1): 88-102. DOI: 10.5204/ijcjsd.v6i1.378.

(cc) EY This work is licensed under a Creative Commons Attribution 4.0 Licence. As an open access journal, articles are free to use, with proper attribution, in educational and other noncommercial settings. ISSN: 2202-8005 


\section{Introduction}

Although the grand narratives of the sociology of punishment (Late Modernism, Postmodernism, Post-Fordism or Neoliberalism) continue to offer a valuable theoretical framework for social sciences, they have some limitations. These narratives privilege knowledge produced in the Global North over other regions of the world and sometimes apply categories of the Global North universally. For this reason, they have recently been problematized in general social theory (Connell 2007) and postcolonial theory (Cunneen 2011), as well as in feminist criminology (Carrington 2014) and southern criminology (see Carrington, Hogg and Sozzo 2016).

At present, relatively few works from within criminology or the sociology of punishment - still mostly carried out in Europe - are studying transitional justice issues which tend to be relegated to 'new trends' in edited collections that draw on perspectives and readings in these disciplines (see the activities of the European Criminology Group on Atrocity Crimes and Transitional Justice (ECACT) of the European Society of Criminology; ${ }^{2}$ also Karstedt 2010; Parmentier 2011; Savelsberg 2010). This novelty in mainstream criminology is mainly related to the impact caused in the Global North by the judging of crimes in Rwanda and the former Yugoslavia and the creation of the International Criminal Court (1998) (Cohen 1995, 1996, 2001; Cunneen 2011; Morrison 2006; Parmentier 2011; Savelsberg 2010; Stanley 2010). The relevance of these events was heightened recently when, in 2009, the Stockholm Prize in Criminology was surprisingly awarded jointly to American John Hagan for his empirical research on the genocide in Darfur and to the Argentinian Raul Zaffaroni for theoretical work on mass crimes (Parmentier 2011: 423).

Even so, studies on the punishment of common crimes and crimes of the state are rarely, if ever, combined in a comprehensive approach. Instead, they are treated as separate and unrelated, assuming different - almost parallel - lines of inquiry, even in places such as Latin America where common crime and the experience of dictatorships and bloody repression make it difficult not to cross these lines of inquiry.

In this paper I aim to contribute to the growing body of scholarship on southern criminology. The coexistence of state crimes (and their memory) along with common crimes establishes a framework of meaning in social relations and penal policies that is usually absent in the explorations of the countries of the Global North. Therefore, I intend to identify some of these features in the discourses and practices of the penality of Argentina and other Latin American countries. Furthermore, although there are deep, detailed studies of penality and punitivism in recent decades in Argentina (see, basically, Sozzo 2011, 2014, 2016b), my intention is to focus on state crimes during three important periods of transitional justice: the1980s, the 1990s and the 2000s.

\section{State crimes and transitional justice in Latin America \\ Dictatorships and transitions to democracy}

In recent decades, many Latin American countries have undergone complex transitions to democracy (the 'third wave' according to Huntington 1993) from the repressive military dictatorships that existed in the 1960s, 1970s and 1980s (for example, in 1973, of the ten Latin American countries of Hispanic origin, only Colombia and Venezuela had democratic governments). State crimes perpetrated by these regimes involved serious violations of human rights, which were qualified, as applicable, as mass crimes, state terrorism or genocide. (State violence involving national armies and para-military groups were also a feature of internal armed conflicts in some South American and Central American countries. ${ }^{3}$ ) The example of Guatemala, for instance, is one of the few Latin American cases almost unanimously qualified by observers as genocide. Several coups took place between 1954 and 1996 and it is estimated that, in 40 years, more than 200,000 people died or disappeared, and 500,000 others, mostly from indigenous communities, became refugees. Between 1982 and 1983, in just 17 months, 100,000 indigenous 
people (mostly men but also many women and children) were brutally killed in front of their families by state troops looking for guerrilleros (Figueroa Ibarra et al. 2013).

Notably, between 1930 and 1983, Argentina experienced six coups d'état led by military interventionism (1930, 1943, 1955, 1962, 1966 and 1976-1983) in between short periods of weak democratic rule. Not all the coups used the same degree of violence and not all of them received the same rejection and resistance from political parties and large sectors of the population. In addition, not all of them were supported by catholic fundamentalism against the 'leftist subversion of Western values' in the context of the cold war, as was the case of the last coup. In this framework, the broad use of violence to solve political conflicts became naturalized. It included media censorship, illegal detentions, breaking and entering, political imprisonment, military controls in the streets, summary executions disguised as confrontation and torture of the opposition (Bergalli 1984; Calveiro 2006; Feld and Franco 2015; Vezzetti 2002).

With a return to democratic rule in Argentina in 1973, state and parastate violence increased alongside civil violence. Nevertheless after the coup of 24 March 1976, together with a new dramatic and systematic increase in the scope and degree of violence, two radical changes dramatically modified the style of historical repression:

First, the disappearances demonstrated the development of an obvious determination on the part of the state to exterminate its opponents. Second, they introduced a new characteristic to politically motivated murder - its clandestine practice. These singularities set the case of Argentina apart, even from the rest of the dictatorships that ruled the countries of the region in the 1970s. (Crenzel 2008b: 174-175)

It also led to the appropriation of almost 500 children and babies who disappeared with their parents or were born in detention centres and were given to other families to assume false identities which remain subject to discovery even to the present day.

The dictatorship toughened the Penal Code with decrees nominated and numbered as 'Laws' passed for many common crimes. In addition to establishing new crimes, the death penalty by firing squad was reinstated (although never applied) and the penalty of absolute disqualification or incapacitation of rights introduced for offenses with 'subversive' motivation (Law 21.338). However, the severity of the penal system was due to authoritarian and clandestine practices. Evidently, official statistics do not account for the effects of these mechanisms, which is why it is difficult to measure them (Sozzo 2016b: 302). Indeed, although there was a police state, common crime was not the main target of repression. Rather, it was one target among many others, including a large number of acts of insubordination (religious, political, sexual, modes of dress, family relationships, music consumption, and so on) that were never legislated as criminal but were deemed as an offense to Catholic and Western moral values which, it was thought, had to be rescued (Crenzel and Allier-Montaño 2015; Feld and Franco 2015; Vezzetti 2002). Thus, leftist armed groups often preferred to be identified as common criminals (and not political enemies) to prevent torture or death.

The boundaries between the systematic state repression and the private, violent and economic crimes of the repressors were blurred. Secret, clandestine and systematic practices of state repression through military, police and paramilitary forces were complementary but they sometimes overlapped, which made it easy to sway public opinion into blaming 'subversive' groups for homicides, robberies and other ordinary crimes. The population's widespread fear of reporting crimes to the police and the courts and the censoring of the media led to an exceptional level of violence management for state and private purposes. Thus, in addition to bureaucratic disappearances, torture and killings, the dictatorship also tolerated (or paid their collaborators with) the spoils of war, sexual abuse, vendettas and private businesses, extortion of alleged 
collaborators of subversion and kidnapping motivated by the repressors' and their allies' personal interests (see Calveiro 2006; Vezzetti 2002: 175-180).

In human rights issues, symbolic acts - even small ones - express powerful meanings and help build tools of political struggle. Today, the evocation of a symbolic number (for example, number of disappeared people) or date, or a label ('subversion', 'dirty war', 'state terrorism' or 'genocide') can constitute emotional political banners. While supporters of the dictatorship identified the use of force as a 'war against subversion', 'communism' or 'terrorism', some of its critics considered it a 'dirty war' (a very controversial concept even today), with tens of thousands of victims, among which were union leaders, workers, priests, human rights lawyers, scientists, doctors and leaders of political parties, their friends, acquaintances and relatives, and others who were deemed suspicious. Human rights groups claim even to this today, as an emblem or symbol, the number of '30,000 disappeared' by 'state terror' in the context of a 'genocide' (Crenzel 2008a; Feierstein 2015; Osiel 1986, 2000: 121).4

In general, in Argentina and in those Latin American countries which had experienced transitional justice, policies, debates and control practices with respect to common or ordinary crimes coexist with those related to truth, memory and justice surrounding serious human rights violations:

... they have been and are still the object of court proceedings, they are part of public discussions and political agendas, they have been portrayed in a wide range of cultural productions, and they have been evoked in urban spaces through archives, parks, monuments, and memory sites, and by way of public policies that seek to ensure that these pasts are conveyed to future generations. (Crenzel and Allier-Montaño 2015: 1)

Latin America does not account for the worst nor the majority of serious human rights violations or mass atrocities (compared with, for example, Nazi Germany and Rwanda) but it helped build a model of individual criminal responsibility for state crimes, whose main precedent had been the trials of Nuremberg and Tokyo after World War II. Argentina also accounts for more than a third of the trials for human rights abuses in the world and most of the transitional justice domestic trials (Nino 1997; Sikkink 1996, 2011; see also Savelsberg 2010; Transitional Justice Database Project 2015).

In this sense, I consider the examination of the Argentine case may contribute to understand the dynamics of penality in other Latin American countries, without forgetting that: '... local specificities that underpin the relationship between democratisation and punishment, [are] embedded ... in national histories, political traditions, economic trajectories, institutional arrangements, and social and cultural dynamics ...' (Cheliotis and Sozzo 2016: 264).

\section{Common and state crime and punishment in Argentina}

Argentina is emblematic in relation to the experience of transitional justice in Latin America and the world, and the developments and debates arising from it (Centro de Estudios Legales y Sociales (Centre for Legal and Social Studies, or CELS) 2013: 128; Osiel 2000; Sikkink 1996, 2011; Teitel 2003). Due to its early development, its impact and the scope of its juridical debates, human rights trials, convictions and sentences, it has had a leading role in the global trend known as 'the justice cascade' (Sikkink 1996, 2011; Crenzel 2015: 81). In her influential book, The Justice Cascade. How Human Rights Prosecutions Are Changing World Politics (2011), political scientist scholar, Katryn Sikkink, analyses the case of Argentina in a separate chapter, titled '... from pariah state to global protagonist'. She suggests that, in the early 1980s, after a non-negotiated transition following the defeat of the Malvinas/Falklands war, Argentina helped the development of accountability mechanisms such as truth commissions (to precede trials, not to replace them as 
South Africa post-apartheid did in the 1990s) and also to establish high-level human rights prosecutions concerning the disappeared ('desaparecidos'). Although earlier military trials had been held in Greece (1975) and Portugal (1979), this unprecedented decision in Latin America was internationally compared with the impact of the Tokyo and Nuremberg trials. Argentina is now also the country with the longest record of prosecuting human rights abuses that occurred before the transition (Sikkink 2011).

Three distinct moments may be identified in the history of trials in Argentina. I examine them concurrently with changes in ordinary crime and punishment.

\section{The origin of the state crime prosecutions}

The first occurrences began in late 1983. Argentina was the sole country in the region not governed by military dictatorships that continued to rule in Bolivia, Brazil, Chile, Paraguay and Uruguay. Democracy had been restored and, five days after Raúl Alfonsín from the Unión Cívica Radical party was sworn in as president (1983-1989), he established a truth commission, the CONADEP (National Commission of Disappeared People) to investigate disappearances of people and other human rights abuses by the military dictatorship. Personalities from culture, journalism, law, religion, congressional politics and science were convened to form the commission. Some human rights activists and groups seeking a bicameral congressional commission declined for different reasons to participate in CONADEP although an exception was the Permanent Assembly for Human Rights or APDH, which voluntarily provided information, testimonies and material to the inquiry. The non-participants included Madres de la Plaza de Mayo and Abuelas de Plaza de Mayo; Centro de Estudios Legales y Sociales (CELS); Servicio de Paz y Justicia (SERPAJ, or Service for Peace and Justice); Familiares de Detenidos y Desparecidos por Razones Políticas o Movimiento Ecuménico por los Derechos Humanos (Ecumenical Movement for Human Rights). These organizations had a dual position since most of them cooperated actively with the CONADEP but publicly continued to call for the establishment of a bicameral commission (Crenzel 2008a, 2008b, 2015).

For over nine months, commission officials and volunteers travelled the country and created local delegations in the search for missing people and evidence of state crimes and their perpetrators, the destruction of evidence, and the existence of a clandestine systematic network of detention and torture centers. After initial disbelief and fear, the work of these commission officials and volunteers generated thousands of new testimonials from other victims, morgue and hospital professionals, police, the military, community leaders, religious leaders and other leaders with first-hand knowledge and experiences of the clandestine torture and detention centers (centros clandestinos de detención) that operated throughout the country under military rule, in Córdoba, Mendoza, Santa Fe and Buenos Aires. That was the case of the notorious Escuela de Mecánica de la Armada (Naval School of Mechanics or ESMA), in a central location in the city of Buenos Aires, where political detainees were tortured and interrogated before being killed. The work of the CONADEP helped prove that these centres had been part of an entire system of state terrorism (Crenzel 2008a: 63, 2008b: 179-181, 2015; Carrington 2014: 87-88).

The final report with the complete record, titled Nunca Más, was presented one year later, in 1984 , to the president on paper and microfilm in a public ceremony. It comprised more than 50,000 pages. A paperback version was published for the information of the general public and became a best seller. (By 2007 Nunca Mas had sold more than half a million copies and had been translated into English, Hebrew, Italian, German and Portuguese.) The evidence collected by CONADEP was the prosecution's key resource in the trials that led to the conviction of the military juntas. To date, all the trials for the crimes of the dictatorship have been based on the report of the CONADEP and there are numerous proposals to create a style of CONADEP for investigating corruption or international terrorism. In addition, 'Nunca Más' is still the main motto in human 
rights discourse and has been a key symbol subsequently replicated in a large number of international truth commission reports. ${ }^{5}$

As a result, in 1985 nine former members of the military juntas were successfully prosecuted in a high federal civil court in Buenos Aires (the trials of the Juntas) and five others (ex-generals Videla, Massera, Agosti, Viola and Lambruschini) were convicted and sentenced according to criminal law (and not the military code) to prison for crimes of aggravated murder, kidnapping and multiple cases of torture. This led to investigations of a large number of people in other courts.

The legality and legitimacy of the criminal justice system to protect ordinary citizens was established based on the rule of law. A liberal criminal orientation was maintained, in which the human rights of the accused and the convicted were reestablished while torture of imprisoned people was punished severely (Sozzo 2014: 13). Criminal classicism of the eighteenth century and its legal safeguards were rediscovered in Anglo-Saxon countries through the 'justice model' and the due process revolution of 1970s. In terms of processes and prison conditions, these guarantees were opposed to the practices of authoritarianism, which were always willing to consider valid any means for crime control. They should be applied by impartial courts administering prospective and strict laws equally to ordinary crimes and state crimes. For this reason, prevention of excessive state violence of any kind was central so as not to relapse into authoritarianism.

Therefore, the National Supreme Court was founded, with the aim of establishing democratic rule through a liberal tendency towards privacy, freedom of speech, search and seizure, arrests, interrogations and drug possession. This approach, inspired by the role of the liberal US Supreme Court (the 'Warren Court') of the 1960s, was absolutely novel in local legal history. This enabled the condemnation of the usual practices of hard repression of the dictatorship through due process, while legitimizing the performance of a liberal criminal justice system to protect citizenship in democracy.

There were no initiatives clearly oriented towards an increase in the extension or severity of the penal system and, in fact, there were several initiatives to decrease it. Thus, international treaties on human rights were ratified; these included the American Convention on Human Rights (Law 23.054), the International Covenant on Civil and Political Rights and the International Covenant on Economic, Social and Cultural Rights (Law 23.313), and the Convention against Torture and Other Cruel, Inhuman or Degrading Treatment or Punishment (Law 23.338) (Gargarella 2010: 29). Further, rules of the Penal Code about recidivism and multi-recidivism, suspended sentences and other stigmatizing measures were modified in favor of convicts. Law 23.070 also established a beneficial computation for common and political prisoners, sentenced or on remand, who were in prison in the period between 24 March 1976 and 10 December 1983 (Sozzo 2011:8).

Although criticism of liberal democracies for tolerance or softness in dealing with common crime existed in Argentina and throughout Latin America (Beckett and Godoy 2008) and elsewhere, this does not always lead to unchanged punitiveness. While state crimes of the dictatorship investigated, prosecuted and convicted for violations of the penal code - were in the spotlight, common crimes, especially so-called street crimes, were not a main concern. The media did not focus on them (except the most sensationalist press, which also sought to sell images of 'the horror show' of the dictatorship); they were not prominent among other problems in public opinion nor were they the focus of the political campaigns of 1985 and 1987 (Sozzo 2014: 6). All of this happened in the context of a considerable increase in the registry of crimes in those years (Kessler 2010: 72). As Sozzo (2011:6) points out:

... between 1983 and 1989, the rate of crime and the rate of intentional homicides recorded by police institutions increased by $73 \%$ and $85 \%$, respectively. In some 
jurisdictions this growth was even higher. In the City of Buenos Aires the rate of property crime - which grew by $65 \%$ in the country - increased by $120 \%$, and by $139 \%$ in the Province of Buenos Aires. In this province the rate of intentional homicide increased by $137 \%$, and by $140 \%$ in the Province of Santa Fe during the same period.

There was one exception I believe is noteworthy: a few cases of kidnappings and murders with the complicity of members or former members of the armed forces, the police or intelligence services attracted deep public concern and media attention because of the menace to democracy they implied (Kessler 2009: 73-75, 2010: 117; Sozzo 2011). These cases were described in official statements as cases of 'unemployed - repressive - labor' (after the dictatorship). Thus, in this period, the greatest fears of crime were associated with the legacy of the authoritarian past. There was no attempt to answer the fears of crime with punitiveness (which referred, precisely, to the authoritarian past) but rather with a further deepening of democratic institutions.

In Argentina, as in many Latin American countries where there are no official data, this period presents serious difficulties in terms of rebuilding data relating to imprisonment (Sozzo 2014: 1, 2016a: 305). However, the data of the federal prison service (which computes data nationwide, including federal prisons throughout the country and prisons in the city of Buenos Aires) and of the provincial prison services of the province of Buenos Aires and the province of Santa Fe (between 1983 and 1989 the city of Buenos Aires, and the provinces mentioned were the three most important demographic districts) may be used as indicators. Thus, between 1983 and 1984 there was a sharp decline of 51 per cent in the number of inmates in the federal prison service, 42 per cent in the prison service of the province of Santa Fe and a 27 per cent in the Province of Buenos Aires. The number in the Federal prison service in 1984 was the lowest since 1965. After 1984, however, annual growth escalated. Federal prisoners increased 11.6 per cent on average, with a large increase of 28 per cent between 1987 and 1988. In 1988 the number of federal prisoners was just 15 per cent, lower than at the end of the military dictatorship. In the province of Buenos Aires and the province of Santa Fe, the growth in the number of prisoners was higher; in 1989 it reached the same number of inmates as at the end of the dictatorship (respectively, 66 per 100,000 and 41 per 100,000) (Sozzo 2014: 18, 2016: 305). This situation changed dramatically after governmental pardons, particularly in the mid-1990s, when both fear of common crime and the indicators of punitiveness grew sharply.

\section{Limits and pardons}

The threat of multiple prosecutions in the Alfonsín government and judicial decisions resulted in armed uprisings against the government as well as a deep public and state fear of a new coup d'etat. In that context, in 1986 and 1987 hierarchical condemnations were prioritized and two laws were passed: one set a deadline in the presentation of new charges ('Punto Final', Law 23.492); and another limited the legal responsibility of soldiers who acted under superior orders ('Obediencia Debida', Law 23.521) except in cases of appropriation of minors. This highly controversial decision, which led to the closure of most of these criminal proceedings, was followed by a decision of the next president - from the opposing Peronist party - that seemed to imply the complete end of trials and punishments.

In 1990, President Menem (1989-1995-1999) launched the rhetoric of social reconciliation and - as chief of the executive branch - pardoned the convicted Junta members and hundreds of military, state officials and some high ranking members of leftist groups that were facing prosecution. The Argentine human rights movement and the families of victims, nevertheless, continued to press for accountability in local and international forums. During the 1990s, there were no criminal prosecutions, but 'Truth trials' were held in some federal courts to gather information about the facts and responsibilities, although there was no prospect of criminal conviction. Relatives and victims also filed complaints with courts in other countries. They 
obtained arrest warrants and extraditions. In 2001, the Inter-American Commission on Human Rights - whose decisions must be followed by its members - ruled against the impunity of amnesty laws and pardons in crimes 'against humanity' (ruling 'Barrios Altos').

The disruption of criminal prosecution and state neglect of the serious crimes committed by the dictatorship can be associated with the emergence of new insecurities which are channeled in the concern for common crime prompted by a populism 'from above' during a decade that was the quintessence of neoliberalism in Argentina (privatizations, de-industrialization and unemployment).

During the 1990s, there was a significant growth in the number of criminal laws produced and, contrary to what had happened during Alfonsín's government, it is possible to identify laws clearly oriented towards increasing the severity and extension of the penal system, but also certain laws oriented towards the opposite (Sozzo 2011, 2016). Many laws implied the criminalization of new behaviors or the increase in punishments for already criminalized behaviors. However, most of them had a marginal impact on the operation of the penal system, being more symbolic than substantive in nature.

It is clear that common crimes became, once again, the center of attention of state reaction. Drug offenses, in the context of the American 'war on drugs', increased in importance and this was reflected in crime statistics after the mid-1990s. In addition, President Menem repeatedly suggested the possibility of reforming criminal law (and abandoning international agreements) to impose the death penalty for trafficking offenses, a proposal which had not existed even during the dictatorship. Although this did not happen, a new drug law that incriminated more behaviours and was more severe was enacted (Law 23.737). In addition, the National Supreme Court upheld more conservative positions on issues including legal guarantees and challenged the liberal position in relation to drugs for personal consumption ('Montalvo' ruling).

However, the bombings in Buenos Aires of the Israeli Embassy in 1992 and the ArgentineIsraelite Mutual Association (AMIA) community center in 1994 - with the alleged complicity of members of state and police forces - resulted in a large number of dead and wounded civilian victims. As a result new, strong demands for mechanisms of accountability and justice against impunity and power crimes were boosted and victim social movements re-emerged together with their demands for truth and justice with regards to the crimes of the dictatorship. 'Insecurity' and crime fears in Argentina became especially widespread after the mid-1990s (Kessler 2009, 2010: 115-138).

In relation to officially registered crimes:

... crime rate in the country grew constantly between 1995 and 2002 (88\%). This increase was similar in Buenos Aires city (87\%) but extremely higher in the Buenos Aires Province (169\%). Intentional homicides grew more moderately in this period in the country (28\%) but to a greater degree in Buenos Aires Province (75\%), compared to a 14\% increase in Buenos Aires city. (Sozzo 2016b: 309)

Contrary to the dynamic of Alfonsín's government, indicators of punitiveness grew:

The federal prison population increased $52 \%$ between 1989 and 1995, reaching a level $28 \%$ higher than at the end of the military dictatorship. The incarceration rate in Buenos Aires Province grew 14\% -reaching a rate 15\% higher than in 1983and in Santa Fe Province it increased 7\% -reaching the same level as in 1983-. Meanwhile, the rate of sentences in the country grew $14 \%$, although it was still $18 \%$ lower than at the end of the military dictatorship. (Sozzo 2016b: 307) 
This trend deepened later on:

Argentinian rate went from 71/100,000 in 1996 to 123/100,000 in 2002, a 73\% increase in six years. A similar growth was observed in Buenos Aires Province $(78 \%)$ and, to a lower degree, in federal prison population (41\%). (Sozzo 2016b: 311)

\section{Restarting the prosecution of state crimes}

Since the candidacy of Alfonsín in 1983, the prosecution of crimes of the dictatorship had not been a political campaign promise; however, twenty years later, during Nestor Kirchner's administration (2003-2007), Congress enacted Law 25.779, which declared the invalidity of 'Punto Final' (Law 23.492) and 'Obediencia Debida' (Law 23.521). In 2005, the National Supreme Court upheld Law 25.779 ('Simon' ruling) and, in 2007, it declared the pardons in relation to the military unconstitutional ('Riveros' ruling). Thus, state crimes of the past were considered 'crimes against humanity' and laws protecting or limiting the prosecution of military personnel and accomplices were considered unconstitutional. This did not extend to political crimes committed by armed leftist organizations. After more than a decade of lethargy, the Kirchner administration called for a new foundation of the struggle for human rights and a questioning of all previous governments (including their own political party). A strong policy of memory, justice and punishment with respect to state crimes of the dictatorial past was installed on the agenda and supported; it was substantially maintained by Kirchner's wife, who succeeded him as president (Cristina Fernández de Kirchner 2007-2011-2015). Human rights organizations and victims' movements strongly supported these policies, and many of them received symbolic and material recognition from the government (to the point of becoming - very controversially - key players in politics) as never before.

This decision revived intense public debates about the dictatorial past and their civilian accomplices. It also triggered a polarization on the recent history and around the silence and crimes of those who had participated in leftist armed organizations prior to the dictatorship.

In sum, from 2003 to the end of 2015, a total of 2,821 people (military, police and civilians) were indicted in hundreds of federal investigations involving multiple participants, promoted in several courts throughout the country. Many of these had been initially investigated in the 1980s until amnesty laws and pardons took effect. The current trend is to group federal investigations around clandestine detention centres or common plans (like the Naval School of Mechanics or ESMA, 'Automotores Orletti', 'Vesuvio' or the jointly developed plan with dictatorships of Chile and Uruguay: 'Plan Condor', and others).

A large number of the accused are still under investigation; some died of natural causes and a few absconded. Strictly speaking, during the years 2006-2015, 662 of those defendants were convicted on trial ${ }^{6}$ and 60 were acquitted. Thirty eight per cent were sentenced to life imprisonment ('prisión' or 'reclusión') with the potential for parole; 31.5 per cent were sentenced to 3-15 years in prison (ordinary prisons for serious crimes, not military prisons); 27 per cent were sentenced to 16-25 years; 3 per cent to no more than three years; and, for the remainder ( 0.5 per cent), a range of other sentences. Nearly one third of the convictions were for offenses of illegal deprivation of liberty; a slightly smaller proportion for torture or murder; and the remainder for appropriation of children, sexual violence or other crimes (CELS 2015; Ministerio Público Fiscal de la Nación (MPF) 2015).

In the election campaign of 2003, Nestor Kirchner, the future president, linked insecurity as a social problem resulting from the crisis, and unemployment and poverty as generated by the neoliberal reforms of the 1990s; he also criticized economic crime and promoted prosecution of 
crimes of the powerful (Sozzo 2016a: 193-94, 2016b: 311). These views were contrary to those of the other leading candidate, the former president Menem.

Between 2006-07 and 2015 there were several legal initiatives and moderate speeches in relation to common crime and no initiatives to increase criminal severity as in the 1990s, with the exception of new incriminations for human trafficking (Law 26.364 and 26.842); , and murder aggravated by 'femicide' and sexual 'hate crimes' (Law 26.791), the impact of which has not yet become clear. This contrasted particularly with rhetoric and initiatives by the Governor of the Province of Buenos Aires, who belonged to the same political alliance and was promoted by Fernández de Kirchner to presidential candidate in 2015. In addition, the National Supreme Court added more prestigious and less conservative members, supported the prosecution of state crimes, and slowly returned to the liberal criminal road of the mid-1980s for common crimes (even in terms of prison overcrowding: rule 'Verbitsky', 2005; and possession of drugs for consumption: rule 'Arriola', 2009).

However, between 2004 and 2005 an event characterized as the best example of punitive populism 'from below' in that decade led to an escalation of penal reforms, undoubtedly aimed at greater punitivity for ordinary crimes. I now focus on this event.

On March 24, 2004, the anniversary of military coup of 1976, President Kirchner removed the picture of Videla, the first president of the dictatorship (who was under house arrest at that moment), from the gallery of the national military college. This move was identified by many as a symbol of a new era in human rights policy. That same day, it became public knowledge that Axel Blumberg had been found killed the previous day. He was a young upper-middle class boy, a victim of a kidnapping organized by a criminal gang with no connection to politics. This case, which became a catalyst for discussions on security and politics, was extensively debated. In Argentina, kidnapping followed by death, as we saw before, is linked not only to fears of political violence by the state but also, during the 1970s, to fears of 'popular' punishment or illegal ways of funding leftist groups and, during the transition to democracy in the 1980s, to fears about persistent authoritarian structures of crime (Kessler 2009, 2010; Sozzo 2011, 2016b).

The 'Axel' Foundation, created by Axel Blumberg's father, held several demonstrations (initially very crowded) in pursuit of security and justice and in favor of moral and legislative reform. He also collected 5 million signatures in a petition to be presented to the executive and legislative authorities of the national government and the Province of Buenos Aires urging passage of a large number of criminal laws, procedural and legal reforms of the prison system, and administrative controls pursuing, undoubtedly, more severity (Calzado and Van den Dooren 2009; Schillagi 2006; Sozzo 2011, 2016b).

In a few months during 2004, in the context of the aforementioned Blumberg crusade, more than ten legal reforms to the Criminal Code and the national prison law increased penalties or restrictions. In October 2004, penitentiary law was also reformed in order to rule out the possibility of enjoying temporary release, or discontinuous prison and assisted liberty in cases of aggravated murder. This was extended to other cases (Calzado and Van den Dooren 2009; Sozzo 2016b).

The relationship of the Kirchner administration to Blumberg's crusade was ambiguous. In the first year, before the great social support of Blumberg's claims, their relationship was close (Blumberg even had personal meetings with the president in the house of government). These meetings helped him gain support for the legal reforms to the Criminal Code mentioned previously. In 2005, long after human rights organizations had questioned the fact that the protests had turned to the political right and criticized the government, Blumberg and the government broke ties. The last public demonstration was in August 2006. A few weeks before, a 
federal court of Buenos Aires city had decided the first conviction for crimes of the dictatorship after 2003.

The upward trend in the national incarceration rate reached 144 per 100,000 inhabitants in 2005:

In Buenos Aires Province, the increase was even higher (28\%). Federal prison population grew less (9\%). Sentence rates increased significantly by $29 \%$. Moreover, the severity of sentences intensified: suspended sentences were reduced - from $42 \%$ in 2002 to 35\% in 2005 - and longer custodial sentences imposed - in 2002, 72\% of these convictions were for less than three years and decreased to $66 \%$ in 2005. (Sozzo 2016b: 313)

However, between 2005 and 2007, there was a slight decrease in the prison population, both nationally and in the Province of Buenos Aires. It then began to increase moderately - in relative terms - until 2015:

Incarceration rate decreased $8 \%$ from 2005 to 2007, reaching 133/100,000, and so did federal prison population by $6 \%$ and in the Buenos Aires Province by $8 \%$. This reduction is also observed in sentence rates: 10\% lower in 2007 than in 2005. (Sozzo 2016b: 314)

In this context, imprisonment rates increased moderately. Between 2007 and 2013 the incarceration rate grew 14\%, reaching 152/100,000 nationwide. In Buenos Aires Province, it increased by 13\% reaching 176/100,000. Federal prison population grew by $9 \%$. Sentence rates remained stable, but the amount of suspended sentences decreased (from $38 \%$ to $32 \%$ ) and so did short custodial sentences (from 66\% to 61\%). (Sozzo 2016b: 316)

\section{Conclusions}

The criminology and sociology of punishment of common crimes and studies on punishment of state crimes have usually taken different paths, even in Latin America where it is extremely difficult not to cross the lines that divide them. In general, in Argentina and transitional justice countries, experiences with respect to common or ordinary crimes coexist with those related to the truth, memory and justice surrounding serious human rights violations.

In this paper I aimed to contribute to the scholarship on southern criminology (Carrington, Hogg and Sozzo 2015) by means of exploring changes in crimes and punishment of state crimes committed during the last military dictatorship in Argentina (1976-1983) jointly with changes in the punishment of common crimes in a - less usual - comprehensive approach.

It is uncertain whether the experience of the authoritarian past will lead to a subsequent punitivity in the democratic criminal justice system, or whether it will prevent a recurrence of authoritarian rule (Cheliotis and Sozzo 2016: 265). However, it appears that the cultivation and maintenance of the collective memory of state crimes of the dictatorship in Argentina makes it very difficult to promote claims of open punitiveness toward ordinary criminality (Sozzo 2011).

It was stressed that the increased tolerance of common crimes of the powerless was possible during the governments of Alfonsín and Kirchner (after 2005) and that matched low rates of imprisonment or, at least, more moderate ones (Sozzo 2016b). This seems to correlate with the policy of prosecuting crimes of the dictatorship. Moreover, punitivity towards common crimes in the mid-1990s could be related to the interruption of trials. 
Criminalizing the repressive practices of the dictatorship as serious human rights violations and legal crimes, according to the civil (not military) Penal Code and courts for federal crimes, had the symbolic and substantive purpose of denying state violence as a legitimate weapon of political struggle. This situation continues today in the identification of these crimes as 'crimes against humanity'. During thirty years of democratic rule, the fear of a military coup did not materialize but neither did violent retaliation against the repressors or waves of lynching motivated by other common crimes, as experienced in other Latin American regions (Godoy 2004).

This article exemplifies a fruitful line of research on punishment in Latin America and other countries with experiences of transitional justice, and also in other parts of the global where these processes have not taken place, as it allows them to test how far their general assumptions about punishment are applicable beyond their borders. Southern criminology should not only challenge the limits of the claims of the grand narratives of the global North but also provide elements to broaden the scope of understanding of their specific problems.

Correspondence: Diego Zysman Quirós, Facultad de Derecho, Universidad de Buenos Aires, Buenos Aires, Argentina; Visiting Fellow, School of Justice, Faculty of Law, Queensland University of Technology, 2 George Street, Brisbane QLD 4000, Australia.

Email: diegozysman@yahoo.com.ar

${ }^{1}$ This paper is part of a research project at Universidad de Buenos Aires, Facultad de Derecho DCT 1440 (2014-16) and UBACyT 20020150200141BA (2016-17) 'Castigo y Democracia: Teoría y práctica penal en Argentina y América Latina'.

2 European Criminology Group on Atrocity Crimes and Transitional Justice (ECACTJ) of the European Society of Criminology at http://www.esc-eurocrim.org/index.php/activities/working-groups/53-atrocity-crimes-andtransitional-justice

3 The transition to democracy began in different years: Ecuador (1980), Bolivia (1982), Honduras (1982) Argentina (1983), El Salvador (1984), Uruguay (1984); Brazil (1985), Guatemala (1986), Haiti (1991), Paraguay (1989), Chile (1990), Panama (1990), Peru (1980, 2000).

4 The CONADEP, in nine months of operation, systematically documented at least 8,961 disappearances. This number increased later with new reports. Human rights groups have claimed, since the mid-1970s, '30.000 disappeared'. Discussions on this issue are not innocent and, even now, they are the subject of intense divisive political and historical tension. Recently, human rights leaders expressed indignation regarding comments of current President Macri on the number of people who had disappeared during the dictatorship and the use of the concept of 'dirty war'. Macri answered in an interview: 'I don't know. It's a debate that I don't want to enter into. If it was 9,000 or 30,000 ...'. The concept of 'dirty war', widely used internationally since $1980 \mathrm{~s}$, or other uses of the term 'war' or 'civil war' to characterize the violence during dictatorship, is questioned by political and human rights organizations and scholars who properly prefer to identify it as state terror and not to speak of two sides with equal responsibility for violence in a civil war.

${ }^{5}$ Arquidiócesis de San Paulo: Brasil Nunca Más (1985); SERPAJ Uruguay, Nunca Más (1989); Comité de Iglesia para Ayudas de Emergencia, Paraguay Nunca Más (1990); Proyecto Interdiocesano de Recuperación de la Memoria Histórica, Guatemala: 'Nunca Más' (1996); ProyectoNunca Más; Colombia 'Nunca Más': crímenes de lesa humanidad (2000), and other commission reports (Crenzel 2008: 193).

6 Despite the criminological importance, a significant number of judgments are not firm in legal terms, since the convicted have the right to appeal to the National Supreme Court.

\section{References}

Allier-Montaño E and Crenzel E (2015) The Struggle for Memory in Latin America. New York: Palgrave Macmillan.

Beckett K and Godoy A (2008) Power, politics and penality: Punitiveness as backlash in American democracies. Studies in Law, Politics and Society 45: 139-173. DOI: 10.1016/S10594337(08)45004-4. 
Bergalli R (1984) Diez últimos años de criminología en Argentina: la epistemología del terror. Revista de la Facultad de Derecho de la Universidad Complutense de Madrid 69: 163-185.

Calveiro P (2006) Poder y desaparición: Los campos de concentración en Argentina. Buenos Aires, Argentina: Colihue.

Calzado M and Van den Dooren S (2009) Leyes Blumberg? Reclamos sociales de seguridad y reformas penales. Delito y Sociedad 27: 97-115.

Carrington K (2014) Feminism and Global Justice. New York: Routledge.

Carrington K, Hogg R and Sozzo M (2016) Southern criminology. British Journal of Criminology 56(1): 1-20. DOI: 10.1093/bjc/azv083.

CELS (2013) Derechos Humanos en Argentina. Informe 2013. Buenos Aires, Argentina: Siglo XXI.

CELS (2015) Derechos Humanos en Argentina. Informe 2015. Buenos Aires, Argentina: Siglo XXI.

Cheliotis L and Sozzo M (2016) Introduction: Democratisation and punishment. Punishment \& Society 18(3): 263-267. DOI: 10.1177/1462474516645691.

Cohen S (1995) State crimes of previous regimes: Knowledge, accountability, and the policing of the past. Law \& Social Inquiry 20(1): 7-50. DOI: 10.1111/j.1747-4469.1995.tb00681.x.

Cohen S (1996) Crime and politics: Spot the difference. British Journal of Sociology 47(1): 1-21.

Cohen S (2001) States of Denial: Knowing about Atrocities and Suffering. Cambridge, United Kingdom: Polity.

Connell R (2007) Southern Theory: The Global Dynamics of Knowledge in the Social Science. Cambridge, United Kingdom: Polity.

Crenzel EA (2008a) La historia política del Nunca Más. Buenos Aires, Argentina: Siglo XXI.

Crenzel EA (2008b) The National Commission on the Disappearance of Persons: Contributions to transitional justice. The International Journal of Transitional Justice 2(2): 173-191. DOI: 10.1093/ijtj/ijn007.

Crenzel EA (2015) Ideas y estrategias de justicia ante la violencia política y las violaciones a los derechos humanos en la transición política en Argentina (1982-1983). In Feld C and Franco M (eds) Democracia, hora cero: actores, políticas y debates en los inicios de la posdictadura: 81-114. Buenos Aires, Argentina: FCE.

Crenzel E and Allier-Montaño E (2015) Introduction. In Allier-Montaño and Crenzel E (eds) The Struggle for Memory in Latin America: 1-12. New York: Palgrave Macmillan.

Cunneen C (2011) Postcolonial perspectives for criminology. In Bosworth M and Hoyle C (eds) What is Criminology?: 249-266. Oxford: Oxford University Press.

Feierstein D (2015) Juicios. Sobre la elaboración del genocidio II. Buenos Aires, Argentina: FCE.

Figueroa Ibarra C, Tischler Visquerra S, Taracena Arriola A, Álvarez Aragón V and Urrutia García E (eds) (2013) Guatemala: Historia reciente (1954-1996). Guatemala: Flacso.

Feld C and Franco M (eds) (2015) Democracia, hora cero: Actores, políticas y debates en los inicios de la posdictadura. Buenos Aires, Argentina: FCE.

Gargarella R (2010). Democracia y derechos en los años de Alfonsin. In Gargarella R, Pecheny M and Murillo M (eds) Discutir Alfonsin: 23-40. Buenos Aires, Argentina: Siglo XXI.

Godoy A (2004) When 'justice' is criminal: Lynchings in contemporary Latin America. Theory and Society 33(6): 621-651. DOI: 10.1023/B:RYSO.0000049192.62380.29.

Huntington S (1993) The Third Wave: Democratization in the Late Twentieth Century. Norman, Oklahoma: University of Oklahoma Press.

Karstedt S (2010) From absence to presence, from silence to voice: Victims in international and transitional justice since the Nuremberg trials. International Review of Victimology 17(1): 930. DOI: 10.1177/026975801001700102.

Kessler G (2009) El sentimiento de inseguridad. Sociología del temor al delito. Buenos Aires, Argentina: Siglo XXI. 
Kessler G (2010) Entre el terrorismo de estado y la 'inseguridad': Delito urbano y política en la transición democrática. In Gargarella R, Pecheny M and Murillo M (eds) Discutir Alfonsin: 115-138. Buenos Aires, Argentina: Siglo XXI.

Ministerio Público Fiscal de la Nación (MPF) (2015) El Estado de las causas por delitos de lesa humanidad en Argentina (al 30 de septiembre). Buenos Aires, Argentina: MPF.

Morrison W (2006) Criminology, Civilization and the New World Order. London: Routledge.

Nino C S (1997) Juicio al mal absoluto. Buenos Aires, Argentina: Emecé.

Osiel M (1986) The making of human rights policy in Argentina: The impact of ideas and interests on a legal conflict. Journal of Latin American Studies 18(01): 135-180.

Osiel M (2000) Why prosecute? Critics of punishment for mass atrocity. Human Rights Quarterly 22(1): 118-147. DOI: 10.1353/hrq.2000.0013.

Parmentier SJ (2011) The missing link: Criminological perspectives on transitional justice and international crimes. In Bosworth M and Hoyle C (eds) What is Criminology?: 380-392. Oxford: Oxford University Press.

Savelsberg J (2010) Crime and Human Rights: Criminology of Genocide and Atrocities. London: Sage

Schillagi C (2006) La obsesión excluyente: las movilizaciones sociales en torno a la cuestión de la (in) seguridad en Argentina durante el año 2004. Temas y Debates 12: 109-137.

Sikkink K (1996) The emergence, evolution, and effectiveness of the Latin American human rights network. In Jelin E and Hershberg E (eds) Constructing Democracy: Human Rights, Citizenship, and Society in Latin America: 59-65. Boulder, Colorado: Westview Press.

Sikkink K (2011) The Justice Cascade: How Human Rights Prosecutions Are Changing World Politics. New York: WW Norton \& Company.

Sozzo M (2011) Transition to democracy and penal policy. The case of Argentina. Straus Working Paper 3/11. School of Law, New York University.

Sozzo M (2014) Democratización y penalidad en la Argentina (1983-1989). Revista de Derecho Penal y Criminología 4(2): 3-32.

Sozzo M (2016a) Posneoliberalismo y penalidad en América del sur. Buenos Aires, Argentina: Clacso.

Sozzo M (2016b) Democratization, politics and punishment in Argentina. Punishment \& Society 18(3): 301-324. DOI: 10.1177/1462474516645689.

Stanley E (2010) Globalization of Transitional Justice. In Chambliss WJ, Michalowski R and Kramer RC (eds) State Crime in the Global Age: 215-231. Portland, Oregon: Willan Publishing.

Teitel RG (2003) Transitional justice genealogy. Harvard Human Rights Journal 16: 69-94. Transitional Justice Database Project (2015) Available at http://www.tjdbproject.com/ (accessed 7 November 2016).

Vezzetti H (2002). Pasado y Presente. Guerra, dictadura y sociedad en la Argentina. Buenos Aires, Argentina: Siglo XXI.

\section{Legislation}

Law No. 21.338, 01/07/1976, Reforma Código Penal: dictadura

Law No. 23.054, 27/03/1984, Pacto San José de Costa Rica: aprobación

Law No. 23.070, 20/07/1984, Prisión Preventiva

Law No. 23.313, 13/05/1986, Pactos Internacionales Derechos Humanos: aprobación

Law No. 23.338, 26/02/1986, Convención Contra la Tortura: aprobación

Law No. 23.492, 29/02/1986, Punto Final

Law No. 23.521, 09/06/1987, Obediencia Debida 
Law No. 25.779, 03/09/2003, Nulidad Punto Final y Obediencia Debida Law No. 26.364, 30/04/2008, Trata de Personas

Law No. 26.791, 14/12/2012, Femicidio

Law No. 26.842, 27/12/2012, Trata de Personas II 